\author{
ACTA MYCOLOGICA \\ Vol. 47 (1): 121-126 \\ 2012
}

\title{
Rhizocarpon lavatum and $R$. reductum (Rhizocarpaceae, Ascomycota), two misunderstood taxa found in the Gorce Mts (Polish Carpathians)
}

\author{
ANNA MATWIEJUK \\ Department of Botany, Institute of Biology, University of Białystok \\ Świerkowa 20B, PL-15-950 Białystok, matwiej@uwb.edu.pl
}

Matwiejuk A.: Rhizocarpon lavatum and R. reductum (Rhizocarpaceae, Ascomycota), two misunderstood taxa found in the Gorce Mts (Polish Carpathians). Acta Mycol. 47 (1): 121-126, 2012.

Based on collections of P. Czarnota deposited in the GPN herbarium, 8 species of Rhizocarpon are reported from the Gorce Mountains. Two of them, R. lavatum and R. reductum are reported from the Gorce Mts for the first time, instead of erroneously determined $R$. obscuratum. This species was previously misinterpreted due to taxonomic and nomenclatoric uncertainties.

Key words: Rhizocarpaceae, lichens, taxonomy, Western Beskidy, national park

\section{INDRODUCTION}

New concepts of taxa and changes in nomenclature have triggered my studies on genus Rhizocarpon. The present paper is the part of the taxonomic revision of representatives of the genus Rhizocarpon in Poland. The paper has been aimed to clarify the actual status of the species belonging to this genus, based on the latest innovations (Fryday 2000; Ihlen 2004). In particular, it is focuses on solving the problem of a group of species interpreted earlier as Rhizocarpon obscuratum (Ach.) Massal.

Rhizocarpon obscuratum from the area of Gorce Mts was reported by Glanc (1960), Czarnota (2000), Czarnota et al. (2005) and Czarnota \& Wojnarowicz (2008).

The thallus of Rhizocarpon obscuratum was usually reported as lacking lichen substances (e.g., Thomson 1997), although Wirth (1995) mention that the thallus sometimes reacts $\mathrm{K}+$ yellow. Dimensions of ascospores were reported as 14-53 $\times$ 6-21 um (Nowak, Tobolewski 1975) or 20-32 × 9-15 $\mu \mathrm{m}$ (Wirth 1995) and 22-50 $\times$ 9-18 um (Thomson 1997).

According to Fryday (2000) the specimens upon which Lecidea petraea var. obscurata Ach., the basionym of Rhizocarpon obscuratum (Ach.) Massal., is based are 
shown to be mostly referable to the species currently known as $R$. lavatum (Fr.) Hazsl. Rhizocarpon reductum Th. Fr. is resurrected to accommodate specimens with small ascospores previously referred there. The name Rhizocarpon obscuratum, which previously had an unclear relation to $R$. lavatum is formally excluded, because it proved to be synonym of Fuscidea lygaea (Ach.) V. Virth \& Vězda (Ihlen 2004). Consequently, the name $R$. reductum (Fryday 2000) has been used for the specimens of this complex producing stictic acid, and $R$. lavatum for the specimens lacking lichen substances.

\section{MATERIAL AND METHODS}

The study is based on the taxonomic revision of Paweł Czarnota's collection made in the Gorce Mts in the years 1994-2005 and stored in the herbarium of the Gorce National Park in Poręba Wielka (GPN). The nomenclature of species is based on taxonomic studies by Ihlen (2004). The species have been named according to Santesson et al. (2004). The pigments Arnoldiana-brown, Atra-brown, Atra-red (sensu Meyer, Printzen 2000) and Macrocarpa-green (sensu Fryday 2002) were recognized. Chemical analyses were performed using a thin-layer chromatography (Orange et al. 2001) with the use of solvents A and C. Localities are given in the system ATPOL adapted for lichens (Cieśliński, Fałtynowicz 1993).

Microscopic measurements of anatomical features (ascospores length, breadth in $\mu \mathrm{m}$ and number of cells per ascospore) were made as characteristic of the diagnostic manual for Rh. lavatum and Rh. reductum. All ascospore measurements were made on mature ascospores and were also granted a definitively on the basis of the 24 spores measured for each species. All published specimens of the six species were previously correctly identified and their localities are in the following papers: Glanc (1960), Czarnota (2000), Czarnota et al. (2005) and Czarnota \& Wojnarowicz (2008).

\section{RESULTS AND DISCUSSION}

As a result of the taxonomic revision, six species of Rhizocarpon have been confirmed in the Gorce Mts, and two new, $R$. lavatum and $R$. reductum, have been distinguished based on their morphology and chemistry. Confirmed species are:

Rhizocarpon distinctum Th. Fr. (Glanc 1960; Czarnota 2000; Czarnota et al. 2005; Czarnota, Wojnarowicz 2008)

Rhizocarpon geminatum Körb. (Czarnota 2000)

Rhizocarpon geographicum (L.) DC. (Czarnota 2000; Czarnota et al. 2005; Czarnota, Wojnarowicz 2008)

Rhizocarpon lecanorinum Anders (Czarnota et al. 2005) 
Rhizocarpon petraeum (Wulfen) A. Massal. (Czarnota et al. 2005; Czarnota, Wojnarowicz 2008)

Rhizocarpon polycarpum (Hepp) Th. Fr. (Czarnota 2000; Czarnota et al. 2005; Czarnota, Wojnarowicz 2008)

Rhizocarpon lavatum (Fr.) Hazsl., Magyar. Birod. Zuzmó-Flór.: 206 (1884)

Syn. Rhizocarpon obscuratum f. lavatum (Fr.) Th. Fr.; Rh. orphninum (Vain.) Vain. (see Ihlen 2004; Santesson et al. 2004)

This species is characterized by the areolate, grey, brown to rust-brown thallus, the flat to convex, rounded areoles, apothecia irregularly arranged, 0.5-1.0 mm diam., with mostly flat disc and distinct margin, epihymenium with intermixed Atrabrown and Macrocarpa-green pigments, exciple in section Atra-brown pigmented, hymenium hyaline, 100-200 $\mu \mathrm{m}$ high, hypothecium dark brown (Arnoldiana-brown), ascospores hyaline, muriform, with (8)10-14(-18) cells in optical view, 30.0-42.0 $\times$ 14-18 $\mu \mathrm{m}$.

Spot test reactions: thallus K-, medulla I-. TLC: lichen products not detected.

To date $R$. lavatum has been reported from Poland only from Beskid Żywiecki Mts: grupa Wielkiej Raczy (Nowak 1998; Bielczyk et al. 2004), Tatra Mts (Flakus 2004, 2007) and the Sudetes: Karkonosze Mts, Mały Śnieżny Kocioł cirque (Kossowska 2009a).

Revised specimens from morphological, anatomical and chemical features matches the description of $R$. lavatum by Ihlen (2004).

SPECIMENS EXAMINED (all previously recognized as $R$. obscuratum (Ach.) Massal.); on siliceous sandstones): Western Beskidy Mts, Gorce Mts: Ge 10 - the road close to Olszowy stream, $690 \mathrm{~m}$ a.s.l., 1994, P. Czarnota \& J. Kiszka (GPN/1894/94); the road on Kosarzyska glade, N slope of Kudłoń Mt., in the catchment Rosochy stream, 22 Oct. 1997, P. Czarnota (GPN/1925/94); Ge 11 - Hucisko glade, valley of Kanina stream, 800 m a.s.l., 3 Oct. 1994, P. Czarnota (GPN/1372/94); the forest road close to Satanowa Polana glade, E slope of Turbaczyk Mt., $900 \mathrm{~m}$ a.s.l. and $940 \mathrm{~m}$ a.s.l., 2 July 1996, P. Czarnota (GPN/1377/94 \& GPN/1465/94); Ge 20 - nature reserve Turbacz, valley of Olszowy stream, $810 \mathrm{~m}$ a.s.l., 21 June 1996, P. Czarnota (GPN/1467/94); Ge 21 - Jaworzyna stream, in the catchment of Łopuszanka stream, 860 m a.s.l., 5 May 1995, P. Czarnota (GPN/1493/94); the road close to Łopuszanka stream, near Żubrowisko glade, 860 m a.s.l., 5 May 1995, P. Czarnota (GPN 1767/94); Ge 22 -S slope of Twarogi, above settlement Ochotnica Dolna - Barbarówka, 530 m a.s.l., 5 Nov. 1999, P. Czarnota (GPN/2153); Lubań range, top of the Lubań Mt., 1200 m a.s.l., 23 June 2004, Wojnarowicz 34.

Rhizocarpon reductum Th. Fr., Lichenogr. Scand. 1: 633 (1874)

Syn. Rhizocarpon obscuratum auct. not. (Ach.) A. Massal.

This species is characterized by the areolate, brown to greyish brown thallus, rounded flat to slightly convex areoles, apothecia irregularly arranged, 0.4-0.6 mm diam., with mostly flat, rough disc and distinct margin, epihymenium with intermixed Atra-brown and Macrocarpa-green pigments, exciple pigmented in section Atrabrown and sometimes also Macrocarpa-green, hymenium hyaline, 100-180 $\mu \mathrm{m}$ high, hypothecium dark brown (Arnoldiana-brown), ascospores hyaline, muriform, with (6-)8-10(-12) cells in optical view, 24.0-26.0 × 8.0-10.0 $\mu \mathrm{m}$.

Spot test reactions: thallus $\mathrm{K}+$ yellow, $\mathrm{C}-$; medulla $\mathrm{I}-, \mathrm{C}-$, $\mathrm{PD}+$ orange. Substances detected by TLC: stictic acid in thallus and apothecia.

Rhizocarpon reductum has been reported from Poland many times, e.g. from the Tuchola Forest (Fałtynowicz 1980), Pojezierze Choszczeńskie lakeland (Lipnicki, Tobolewski 1991), Suwalski Landscape Park (Kukwa, Fałtynowicz 2002; 
Zalewska et al. 2004), Białowieża Forest (Sparrius 2003), Bieszczady National Park (Kościelniak, Kiszka 2006), Podlasie (Matwiejuk 2007, 2009), Karkonosze Mts: Czarny Grzbiet ridge (Kossowska 2009b) and Beskid Żywiecki (Matwiejuk 2011).

Revised specimens from morphological, anatomical and chemical features matches the description of $R$. reductum by Fryday (2000) and Ihlen (2004).

SPECIMENS EXAMINED (all previously recognized as $R$. obscuratum (Ach.) Massal.; on siliceous sandstones): Western Beskidy Mts, Gorce Mts: Ge 21 - Nowa glade, below Kiczora Mt., 1220 m a.s.l., 6 Nov. 1997, P. Czarnota (GPN/1913/94); Ge 22 - S slope of Twarogi Mt., above settlement Ochotnica Dolna Barbarówka, 530 m a.s.1., 5 Nov. 1999, P. Czarnota (GPN2131).

Taxonomic and nomenclatural remarks. Rhizocarpon reductum sometimes resembles some forms of $R$. lavatum with small apothecia, but the presence of stictic acid usually makes it distinct. A comparison of the main features distinguishing Rhizocarpon lavatum and $R$. reductum is presented in the Table 1.

The distinction of the two species - Rhizocarpon lavatum and $R$. reductum is related to the changes in the taxonomy of Rhizocarpon obscuratum auct. non (Ach.) Massal. complex, with hyaline and muriform ascospores (Fryday 2000; Ihlen 2004).

Rhizocarpon lavatum is similar to $R$. reductum, a name resurrected for the species previously commonly referred to R. obscuratum (Ach.) A. Massal. (Fryday 2000). Basionym for $R$. obscuratum, Lecidea petraea var. obscurata Ach. has been show to be based on a mixed type (Fryday 2000) and to be regarded as a synonym of Fuscidea lygaea (Ach.) V. Virth \& Vězda (Ihlen, Fryday 2002; Ihlen 2004). An examination of the specimens upon which Rhizocarpon obscuratum is based revealed that they are mostly referable to the species currently knows as $R$. lavatum. Rhizocarpon reductum is resurrected for specimens formely placed under 'R. obscuratum' with small ascospores and the thallus containing stictic acid, whereas specimens with larger ascospores and a thallus lacking lichen substances are more referred to $R$. lavatum (Fryday 2000).

Table 1

Comparison of the main features separating Rhizocarpon lavatum and R. reductum

\begin{tabular}{|c|c|c|}
\hline & Rhizocarpon lavatum & Rhizocarpon reductum \\
\hline Principal habitat & siliceous sandstones & siliceous sandstones \\
\hline Thallus & $\begin{array}{l}\text { grey, brown to rust-brown, } \\
\text { areolate }\end{array}$ & $\begin{array}{l}\text { brown to greyish brown, } \\
\text { areolate }\end{array}$ \\
\hline \multicolumn{3}{|l|}{ Chemistry: } \\
\hline Lichen products & not detected & stictic acid \\
\hline Spot test reactions & thallus $\mathrm{K}_{-}$ & thallus $\mathrm{K}+$ yellow \\
\hline Diameter of apothecia $(\mathrm{mm})$ & $0.5-1.0$ & $0.4-0.6$ \\
\hline \multicolumn{3}{|l|}{ Ascospores: } \\
\hline Lenght & $30.0-42.0$ & $24.0-26.0$ \\
\hline Breadth & $14.0-18.0$ & $8.0-10.0$ \\
\hline $\begin{array}{l}\text { Number of cells in optical } \\
\text { sections }\end{array}$ & $(8-) 10-14(-18)$ & $(6-) 8-10(-12)$ \\
\hline \multicolumn{3}{|l|}{$\begin{array}{l}\text { Location of the insoluble } \\
\text { lichen pigments }\end{array}$} \\
\hline Hypothecium & Arnoldiana-brown & Arnoldiana-brown \\
\hline Epihymenium & $\begin{array}{l}\text { Atra-brown and Macrocarpa- } \\
\text { green }\end{array}$ & $\begin{array}{c}\text { Atra-brown and Macrocarpa- } \\
\text { green }\end{array}$ \\
\hline Exciple & Atra-brown & Atra-brown \\
\hline
\end{tabular}


Acknowledgements. I would like to express my warmest thanks to Paweł Czarnota, for facilities of collection of Rhizocarpon. I wish to express my thanks to the reviewer for his precious remarks and advice.

\section{REFERENCES}

Bielczyk U., Lackovičová A., Farkas E.E., Lőkös L., Breuss O., Kondratyuk S. Ya. 2004. Checklist of lichens of the Western Carpathians. W. Szafer Institute of Botany, Polish Academy of Sciences, Kraków.

Cieśliński S., Fałtynowicz W. 1993. Note from editors.(In:) S. Cieśliński, W. Fałtynowicz (eds). Atlas of the geographical distribution of lichens in Poland. 1: 7-8. W. Szafer Institute of Botany of Polish Academy of Sciences, Kraków.

Czarnota P. 2000. Porosty Gorczańskiego Parku Narodowego. I. Wykaz i rozmieszczenie gatunków. Parki nar. Rez. Przyr. 19 (1): 3-73.

Czarnota P., Glanc K., Nowak J. 2005. Materiały do bioty porostów Gorców ze zbiorów Herbarium Instituti Botanici Polskiej Akademii Nauk w Krakowie. Fragm. Flor. Geobot. Polonica 12.2: 327-370.

Czarnota P., Wojnarowicz A. 2008. Porosty i grzyby naporostowe północnej części grupy Lubania w Gorcach. Ochrona Beskidów Zachodnich 2: 21-49.

Fałtynowicz W. 1980. Porosty północno-zachodniej części Borów Tucholskich. Fragm. Flor. Geobot. 26 (1): 81-102.

Flakus A. 2004. New and rare lichen species of the Polish Tatra Mountains. Polish Bot. J. 49 (1): $79-91$.

Flakus A. 2007. Lichenized and lichenicolous fungi from mylonitized areas of the subnival belt in the Tatra Mountains (Western Carpathians). Ann. Bot. Fennici 44: 427-449.

Fryday A. M. 2000. On Rhizocarpon obscuratum (Ach.) Massal., with notes on some related species in the British Isles. Lichenologist 32: 207-224.

Fryday A. M. 2002. A revision of the species of the Rhizocarpon hochstetteri group occurring in the British Isles. Lichenologist 34: 451-477.

Glanc K. 1960. Interesujące i rzadkie gatunki porostów z Gorców. Fragm. Flor. Geobot. 6(4): 601-608.

Ihlen P. G. 2004. Taxonomy of the non-yellow species of Rhizocarpon (Rhizocarpaceae, lichenized Ascomycota) in the Nordic countries, with hyaline and muriform ascospores. Mycol. Res. 108: 533-570.

Ihlen P. G., Fryday A. M. 2002. Rhizocarpon timdalii, a new species from north-west Europe and northeast North America. Lichenologist 34 (2): 95-100.

Kossowska M. 2009a. Rewizja zbiorów lichenologicznych z żyły bazaltowej w Małym Śnieżnym Kotle (Karkonosze) zachowanych w zielniku KRAP. Fragm. Flor. Geobot. Polonica 16 (1): 135-143.

Kossowska M. 2009b. Materiały do rozmieszczenia porostów naskalnych w Karkonoszach. I. Grunty strukturalne Czarnego Grzbietu. Acta Bot. Siles. 4: 161-169.

Kościelniak R., Kiszka J. 2006. Nowe i rzadkie gatunki porostów Lichenes w Bieszczadzkim Parku Narodowym i jego otulinie. VIII. Roczniki Bieszczadzkie 14: 135-138.

Kukwa M., Fałtynowicz W. 2002. Porosty i grzyby naporostowe rezerwatu „Głazowisko Bachanowo nad Czarną Hańczą” i terenów przyległych w Suwalskim Parku Krajobrazowym (NE Polska). Parki nar. Rez. Przyr. 21 (4): 375 -384.

Lipnicki L., Tobolewski Z. 1991. Porosty Pojezierza Choszczeńskiego. Acta Mycol. 27 (1): 7 -30.

Matwiejuk A. 2007. Porosty Białegostoku. Analiza florystyczno-ekologiczna, Wydawnictwo Ekonomia i Środowisko, Białystok.

Matwiejuk A. 2009. Porosty miejscowości Boćki i okolic na Podlasiu (NE Polska). Opole Scientific Society Nature Journal 42: 49-61.

Matwiejuk A. 2011. Rhizocarpon reductum (Rhizocarpaceae) - nowy gatunek w biocie porostów Beskidu Żywieckiego (Polska, Karpaty Zachodnie). Fragm. Flor. Geobot. Polonica 18 (1): 39-41.

Meyer B., Printzen C. 2000. Proposal for a standarized nomenclature and characterization of insoluble lichen pigments. Lichenologist 32: 571-583.

Nowak J. 1998. Porosty Beskidów Wyspowego i Żywieckiego, Pasma Jałowca i Masywu Babiej Góry. Monogr. Bot. 83: 1-131.

Nowak J., Tobolewski Z. 1975. Porosty polskie. Opisy i klucze do oznaczania porostów w Polsce dotychczas stwierdzonych lub prawdopodobnych. PWN, Warszawa-Kraków.

Orange A., James P. W., White, F. J. 2001. Microchemical methods for the identification of lichens. British Lichen Society, London. 
Santesson R., Moberg R., Nordin A., Tønsberg T., Vitikainen O. 2004. Lichen-forming and lichenicolous fungi of Fennoscandia. Museum of Evolution, Upssala University.

Sparrius L. B. 2003. Contribution to the lichen floras of the Białowieza Forest and the Biebrza Valley (Eastern Poland). Herzogia 16: 155-160.

Thomson J. W. 1997. American Arctic lichens 2. The microlichens. Madison, University of Wisconsin Press, $675 \mathrm{pp}$.

Wirth V. 1995. Die Flechten Baden-Württembergs. Bd.1-2, II Aufl. Stuttgart, Verl. Eugen Ulmer.

Zalewska A., Fałtynowicz W., Krzysztofiak A., Krzysztofiak L., Picińska-Fałtynowicz J. 2004. Lichens of Suwalski Landscape Park. (In:) A. Zalewska, W. Fałtynowicz (eds). Lichens of the protected areas in the Euroregion Niemen, "Man and Nature" Association, Suwałki: 5-50.

Rhizocarpon lavatum i R. reductum (Rhizocarpaceae, Ascomycota), dwa nieznane dotąd taksony stwierdzone w Gorcach (Polskie Karpaty)

\section{Streszczenie}

W zbiorach zielnikowych GPN z Gorców stwierdzono 8 gatunków Rhizocarpon (R. distinctum, $R$. geminatum, $R$. geographicum, $R$. lavatum, $R$. lecanorinum, $R$. petraeum, $R$. polycarpum, $R$. reductum). Po raz pierwszy dla tego terenu podano dwa gatunki Rhizocarpon lavatum i $R$. reductum. Wyróżnienie nowych gatunków związane jest ze zmianą ujęcia taksonomicznego i nomenklatorycznego reprezentantów grupy Rhizocarpon obscuratum auct., charakteryzujących się bezbarwnymi i murkowatymi zarodnikami (Fryday 2000; Ihlen 2004). W oznaczeniu tych gatunków wykorzystano chromatografię cienkowarstwową (TLC), która pozwoliła określić ich cechy chemiczne: obecność kwasu stiktowego u R. reductum i brak wtórnych metabolitów u $R$. lavatum. Pierwszy z tych gatunków charakteryzuje się ponadto mniejszymi i mniej podzielonymi zarodnikami [24.0-26.0×8.0-10.0 $\mu \mathrm{m},(6-) 8-10(-12)$ komórek], podczas gdy zarodniki $R$. lavatum osiągają rozmiary 30.0-42.0×14.0-18.0 $\mu \mathrm{m}$ i są podzielone na (8-)1014(-18) komórek. 